\title{
Biomarkers in the rock outcrop of the Kazusa Group reveal paleoenvironments of the Kuroshio region
}

\section{HIROTO KAJITA ( $\nabla$ kajita@aori.u-tokyo.ac.jp )}

The University of Tokyo https://orcid.org/0000-0003-0399-6483

\section{Ayumi Maeda}

The University of Tokyo

\section{Masayuki Utsunomiya}

National Institute of Advanced Industrial Science and Technology

\section{Toshihiro Yoshimura}

Japan Agency for Marine-Earth Science and Technology https://orcid.org/0000-0003-0478-4239

\section{Naohiko Ohkouchi}

Japan Agency for Marine-Earth Science and Technology

\section{Atsushi Suzuki}

National Institute of Advanced Industrial Science and Technology

\section{Hodaka Kawahata}

The University of Tokyo

\section{Article}

Keywords: Iong-chain alkenones, n-alkanes, biomarkers, oceanic and atmospheric changes

Posted Date: September 28th, 2020

DOI: https://doi.org/10.21203/rs.3.rs-72985/v1

License: (c) (1) This work is licensed under a Creative Commons Attribution 4.0 International License.

Read Full License

Version of Record: A version of this preprint was published at Communications Earth \& Environment on May 10th, 2021. See the published version at https://doi.org/10.1038/s43247-021-00154-2. 


\section{Biomarkers in the rock outcrop of the Kazusa Group reveal}

2 paleoenvironments of the Kuroshio region

3 Hiroto Kajita ${ }^{1,2,3,4,}{ }^{*}$, Ayumi Maeda ${ }^{1,2,3,4}$, Masayuki Utsunomiya ${ }^{3}$, Toshihiro Yoshimura ${ }^{4}$,

4 Naohiko Ohkouchi ${ }^{4}$, Atsushi Suzuki ${ }^{3}$, Hodaka Kawahata, ${ }^{1,2}$

$5{ }^{1}$ Atmosphere and Ocean Research Institute, University of Tokyo, 5-1-5, Japan

$6 \quad{ }^{2}$ Department of Earth and Planetary Science, Graduate School of Science, University of Tokyo, Japan

$7 \quad{ }^{3}$ Geological Survey of Japan, National Institute of Advanced Industrial Science and Technology, Japan

$8{ }^{4}$ Biogeochemistry Research Center, Japan Agency for Marine-Earth Science and Technology, Japan

9 * Correspondence: H.K., Email: kajita322@frontier.hokudai.ac.jp, Tel: (+81) 0471366135 


\section{Abstract}

12 The classical biomarkers of long-chain alkenones and $n$-alkanes preserved in marine and lake

13 sediment cores are widely used to reconstruct paleoenvironments. Here, we detected these

14 biomarkers are preserved in the rock outcrop of the Kazusa Group exposed in central Japan, the

15 most continuous sedimentary succession in the world, covering almost the entire Pleistocene.

16 The alkenone unsaturation ratio and average chain length of $n$-alkanes appeared to reflect the

17 glacial-interglacial changes in the sea surface temperature (SST) and terrestrial climate,

18 respectively. Alkenone-based SSTs during 1.1-1.0 Ma were significantly higher than present-

19 day SSTs in the same area, as supported by foraminiferal $\mathrm{Mg} / \mathrm{Ca}$-based temperatures, possibly

20 reflecting the direct intrusion of the warm Kuroshio Current. Applying these biomarkers, which

21 might be circumstantially preserved owing to their immunity to high temperature and

22 consolidation stress during burial and uplift, we expect that the Kazusa Group should reveal

23 detailed oceanic and atmospheric changes of the Kuroshio region. 
Introduction

Long-chain alkenones (LCAs) are $\mathrm{C}_{35}-\mathrm{C}_{42}$ unsaturated methyl and ethyl ketones with 2-4

27 double bonds and feature unique lipid biomarkers produced by Isochrysidales haptophytes living

28 in surface waters ${ }^{1}$. The degree of unsaturation in $\mathrm{C}_{37}$ alkenones $\left(\mathrm{U}_{37}^{\mathrm{K}}\right)$ is strongly correlated with

29 the growth temperature in culture experiments, and is widely used as one of the most quantitative

30 and well-established proxies for sea surface temperature (SST) ${ }^{2-4}$. High-molecular $\left(>\mathrm{C}_{27}\right) n$ -

31 alkanes with odd/even predominance are derived from terrestrial higher plants ${ }^{5,6}$ and are used to

32 reconstruct changes in the temperature, humidity, and vegetation based on the carbon number

33 distributions ${ }^{7,8}$. These paleoenvironmental indexes are traditionally applied to marine and lake

34 sediment cores, but are rarely applied to exposed sedimentary rocks because LCAs and $n$-alkanes

35 can undergo maturation at high temperature and lose their initial paleoenvironmental

36 information ${ }^{9,10}$. Several previous studies have detected LCAs and $n$-alkanes from outcrops;

37 however, only a few studies conducted on the outcrops around the Mediterranean Sea,

38 reproduced distinct glacial-interglacial-scale climate changes using $\mathrm{U}_{37}^{\mathrm{K}^{\prime}}$, and there are no studies

39 in which $n$-alkane-based indexes were used ${ }^{7,11,12}$.

40 The Kazusa Group represents the infill of the Plio-Pleistocene Kazusa forearc basin that

41 developed in response to the subduction of the Pacific and Philippine Sea plates beneath the

42 North American plate, and is well exposed in the Boso Peninsula, Chiba Prefecture, central

$43 \operatorname{Japan}^{13}$ (Fig. 1). The middle to lower part of the Kazusa Group is represented by successions of

44 submarine fan deposits associated with deep-sea, basin-plain, and slope deposits, and is one of

45 the most continuous of exposed sedimentary successions with a high sedimentation rate (ca. 1.5

$46 \mathrm{~m} / \mathrm{kyr}$ on average) in the world covering almost the entire Pleistocene ${ }^{13,14}$. It contains marine

47 microfossils, paleomagnetic reversals, and a large number of tephra beds, which allow us to 
establish a robust chronological and stratigraphic framework and undertake paleoceanographic

49 and paleoclimatic studies with high time-resolution ${ }^{15}$ (Supplementary Fig. 1). These studies are

50 recognised worldwide, and the Chiba composite section in the Kazusa Group was certified in

512020 as the Global Boundary Stratotype Section and Point (GSSP) between the Chibanian and

52 Calabrian stages ${ }^{16}$.

53 The Boso Peninsula is located near the Kuroshio Extension Front (KEF), where the

54 Kuroshio Current (KC) leaves the coast of Japan. The KC transports warm and saline water from

55 the equatorial Western Pacific Warm Pool (WPWP) to northern mid-latitudes, and forms

56 pronounced latitudinal gradients in SST off the Boso Peninsula ${ }^{17}$ (Supplementary Fig. 2). It is

57 also located at the northern limit of the seasonal progression of the westerly jet that bounds the

58 East Asian monsoon (EAM) front ${ }^{18}$. Thus, the oceanic and terrestrial conditions around the

59 Kazusa forearc basin should be responsive to shifts in the KEF and EAM, which are related to

60 the modulations in the dynamics of Hadley cells in the northern hemisphere ${ }^{17,18}$. Therefore, the

61 paleoenvironmental information, especially SST, stored in the Kazusa Group could be important

62 for understanding the changes in global climate systems during the Pleistocene. However, there

63 has been no widely applicable quantitative proxy for SST owing to the extremely small standing

64 stock and poor preservation of surface-dwelling planktic foraminifera. In this study, we

65 discovered that multiple classical biomarkers, LCAs and odd preference $n$-alkanes, are well

66 preserved in several sections of the Kazusa Group and can be used as paleoenvironmental

67 indicators. 


\section{Geological setting and sample collections}

71 The Otadai Formation in the Kazusa Group consists of alternations of turbidite sandstone

72 and hemipelagic siltstone beds which had developed as deep-sea submarine fan systems from 1.2

73 to $1.0 \mathrm{Ma}^{13}$. Frequently intercalated tuff beds in the Otadai Formation allows lateral bed-by-bed

74 correlation of turbidite sandstone and siltstone beds ${ }^{19}$. Detailed oxygen isotope stratigraphy for

75 the upper to middle Otadai Formation was established using benthic foraminifera recovered from

76 the TR-3 core, which was confirmed by fission-track ages of zircon from key intercalated tuff

77 beds, as well as magnetostratigraphy and biostratigraphy ${ }^{20}$ (Fig. 2a). This chronological model

78 was applied by correlations between TR-3 and the outcrops using comparison with key tuff beds

79 (named $\mathrm{O} 4, \mathrm{O} 4.5, \mathrm{O} 7, \mathrm{O} 11, \mathrm{O} 12, \mathrm{O} 16$, and $\mathrm{O} 18)^{21}$, which were identified based on visual

80 observations, mineral compositions, and refractive index of volcanic glass ${ }^{20}$. We collected

81 samples from the outcrops exposed along the Yoro River, which correspond to MIS 33 to 29

82 (Supplementary Figs. 3a, 4). To investigate data variability within a single siltstone bed, six

83 samples were taken from the siltstone bed ca. $10 \mathrm{~cm}$ below the 018 key tuff bed along the

84 bedding plane and the turbidite sandstone directly beneath the siltstone bed (Supplementary Fig.

85 5). The $\mathrm{O} 7$ and $\mathrm{O} 11$ key tuff beds were also exposed at the Shoryuji section located $10 \mathrm{~km}$ east

86 of the Yoro River section ${ }^{22}$. Siltstone samples were taken directly above and below the O7 and

87 O11 key tuff beds in each section to compare the data from the same stratigraphic level

88 (Supplementary Figs. 3b, 4). All samples for laboratory analysis were taken from the bluish-grey

89 part exposed after removing the weathered surface coating on the outcrop.

90

91 


\section{Results and Discussion}

\section{LCAs and $\boldsymbol{n}$-alkanes based proxies as paleoenvironmental indicators}

$\mathrm{C}_{37}-\mathrm{C}_{39} \mathrm{LCAs}$ and odd preference $\mathrm{C}_{26}-\mathrm{C}_{36} n$-alkanes were detected in all samples that we

95 analysed (Supplementary Fig. 6). The preservation of these biomarkers is probably due to the

96 Kazusa Group never having been exposed to high temperatures or consolidation stress during

97 burial and uplift. The paleo-maximum temperature and maximum burial depth deduced from

98 vitrinite reflectance and consolidation tests in the Otadai Formation were $<45^{\circ} \mathrm{C}$ and $7.6 \mathrm{MPa}$,

99 respectively ${ }^{23}$. According to hydrous pyrolysis experiments, the LCAs and $n$-alkane based

100 indices did not change under these conditions at laboratory time scales $(\sim \text { days })^{9,10}$.

101 The alkenone unsaturation ratio $\left(\mathrm{U}_{37}^{\mathrm{K}^{\prime}}\right)$, average chain length (ACL) and carbon preference

102 index (CPI) of $n$-alkanes (see Fig. 2 for each definition) from the Yoro River section ranged

$103 \quad 0.795-0.921,30.1-31.0$, and 3.66-6.02, respectively, showing variations synchronised with the

104 glacial and interglacial cycles from MIS 33 to 29 (Fig. 2). Alternatively, the relative compounds

105 of total organic carbon and total nitrogen ( $\mathrm{C} / \mathrm{N}$ ratios), indicating relative contributions of

106 terrestrial and marine organic matter (see Methods for the detail), were not completely

107 synchronised with the glacial-interglacial cycles, suggesting that the accumulation process of

108 organic compounds was controlled not only by sea-level changes but also by the effects of

109 topography and redeposition in submarine fans (Fig. 2). $\mathrm{U}_{37}^{\mathrm{K}^{\prime}}$, ACL, and CPI values from the

110 Shoryuji section coincided with the values from the correlative siltstone bed of the Yoro River

111 section within the data variability $(2 \sigma)$ of the single siltstone bed shown in Supplementary Table

112 1, which confirms that these indexes immune from the effects of topography in the submarine

113 fan and faithfully reflect the representative environment around the Kazusa forearc basin (Table

114 1). The turbidite sandstone and the adjacent siltstones had closely similar $\mathrm{U}_{37}^{\mathrm{K}}$ and ACL values 
115 (Supplementary Table 1), which indicates that these values changed negligibly due to

116 alternations of redox condition caused by turbidites, as is partly suggested by ref. 24 . In contrast,

117 the turbidite sand bed, which might have been redeposited from a shallower seabed ${ }^{19}$, had a

118 significantly higher $\mathrm{C} / \mathrm{N}$ ratio and lower CPI value than the siltstones (Supplementary Table 1).

$119 \mathrm{U}_{37}^{\mathrm{K}^{\prime}}$ must reflect the temperature fluctuation in the Kazusa forearc basin at water depths

120 of $0-50 \mathrm{~m}$, where LCAs are mostly produced $^{25}$. The transportation routes of $n$-alkanes are

121 enigmatic because they can be supplied not only as river suspensions but also as aeolian dust ${ }^{26}$.

122 However, we believe that ACL and CPI fluctuations mostly reflect monsoonal climate changes

123 in the hinterland of the Kazusa forearc basin because higher ACL and lower CPI values have

124 been detected in the lower latitudes of present-day surface soils in East Asia as well as of

125 aerosols in the western Pacific ${ }^{27-29}$. CPI values weakly correlate with $\mathrm{C} / \mathrm{N}$ ratios $\left(\mathrm{R}^{2}=0.31, \mathrm{p}<\right.$

126 0.01), whereas $U_{37}^{K^{\prime}}$ and ACL do not (Supplementary Fig. 7). Therefore, CPI may also be

127 influenced by the freshness of higher plant $n$-alkanes, that is, it declined through dilution and

128 degradation of terrestrial plant derived material during offshore transportation and redeposition

129 processes $^{6,30}$. Based on the above observations, we conclude that $\mathrm{U}_{37}^{\mathrm{K}^{\prime}}$ and ACL are less

130 susceptible to the effects of sedimentation process and diagenesis, which can be excellent

131 paleoenvironmental indicators for the Kazusa forearc basin. The periods and amplitudes of the

132 terrestrial climate fluctuations indicated by ACL were almost synchronised with those of the

133 oxygen isotope ratios of benthic foraminifera $\left(\delta^{18} \mathrm{OBF}\right)$ (Fig. 2a, c). $U_{37}^{K^{\prime}}$ values in the moderate

134 interglacial periods (MIS 29 and 33) were comparable with those in the extreme interglacial

135 period (MIS31) (Fig. 2a, b). The reason for the difference in the fluctuation pattern of $U_{37}^{K^{\prime}}$ and

136 those of ACL and $\delta^{18} \mathrm{O}_{\mathrm{BF}}$ can be attributed to the effect of ocean currents, as discussed in the

137 next section. 


\section{Quantitative temperature reconstructions and implications for paleoceanography}

142 calibration may be affected by changes in the assemblages of the alkenone synthesisers, but the

143 evolutionary events and changes in species dominance within the coccolithophore populations

144 are considered to have had little impact on the relationship between $\mathrm{U}_{37}^{\mathrm{K}^{\prime}}$ and SST during the

145 Pleistocene ${ }^{31,32}$. The $\mathrm{U}_{37^{\mathrm{K}}}^{\mathrm{\prime}}$-SSTs during MIS 33 to 29 were calculated from $22.8^{\circ} \mathrm{C}$ to $26.6^{\circ} \mathrm{C}$.

146 Fluctuations in the $\mathrm{U}_{37^{\prime}}^{\mathrm{K}^{\prime}}$-SST near the Boso Peninsula have been previously reported from the

147 core site of MD01-2421 covering MIS 1-5e $\mathrm{e}^{33}$ (Fig. 1). Comparing periods with similar ice

148 volumes estimated from the global $\delta^{18} \mathrm{OBF}$ profile ${ }^{34,35}$, the $\mathrm{U}_{37^{\mathrm{K}}}^{\mathrm{K}} \mathrm{SST}$ s in the Otadai Formation

149 appeared to be $4-7{ }^{\circ} \mathrm{C}$ higher than those of the MD01-2421 core, located near the KEF (Table 2).

150 The ratio of magnesium to calcium $(\mathrm{Mg} / \mathrm{Ca})$ of planktic foraminifera is an additional established

151 paleotemperature proxy ${ }^{36}$. From the five selected beds with relatively large amounts of

152 foraminiferal standing stock, we analysed $\mathrm{Mg} / \mathrm{Ca}$ paleotemperatures of Globigerina bulloides

153 ( $\mathrm{T}_{\text {bul }}$ ), which were abundant at depths shallower than $40 \mathrm{~m}$ near the Boso Peninsula ${ }^{37}$. T bul

154 showed $19.9-21.9{ }^{\circ} \mathrm{C}$ and $22.5-24.8^{\circ} \mathrm{C}$ in the glacial and interglacial periods, respectively, and

155 these values are at least $4{ }^{\circ} \mathrm{C}$ higher than the Tbul from the MD01-2421 core ${ }^{38}$, thereby supporting

156 the validity of the high $\mathrm{U}_{37^{\prime}}^{\mathrm{K}^{\prime}}-\mathrm{SST}$ (Table 2 ). The $1-4{ }^{\circ} \mathrm{C}$ offsets between the $\mathrm{U}_{37^{\prime}}^{\mathrm{K}}-\mathrm{SST}$ and $\mathrm{T}$ bul can

157 be attributed to differences in the production seasons near the Boso Peninsula, insofar as

158 alkenones are mostly produced in $\mathrm{July}^{25}$, whereas G. bulloides are most abundant during the

159 spring phytoplankton bloom ${ }^{39}$. Although these temperature offsets do not seem to be constant,

160 similar trends can be often seen in previous studies using marine sedimentary cores ${ }^{40,41}$, which is 
161 due to that the high production season for G. bulloides can differ because their production is 162 greatly influenced by nutrient availability ${ }^{42}$.

163 The $\mathrm{U}_{37^{\prime}}^{\mathrm{K}^{\prime}} \mathrm{SST}$ in in the Otadai Formation are still $2-3{ }^{\circ} \mathrm{C}$ higher than those reported from

164 the St. 14 core covering MIS 1-2, located near the mainstream of the $\mathrm{KC}^{43}$ (Fig. 1a, Table 2).

165 Considering the distribution of SSTs around the core sites of MD01-2421 and St. 14

166 (Supplementary Fig. 1), we interpret that the Kazusa forearc basin was located under the direct

167 influence of the $\mathrm{KC}$, and the temperatures of the warm water masses in the interglacial periods

168 (MIS 29, 31, and 33) may have been higher than those in the Holocene (MIS 1). We also

169 assumed that the KC could still have had a large influence on the Kazusa forearc basin even in

170 the glacial periods (MIS 30 and 32) compared to those in the last glacial period (MIS 2) when the

171 KEF had shifted to the south ${ }^{43}$. Previous studies using marine sediment cores have revealed 1-2

$172{ }^{\circ} \mathrm{C}$-higher SSTs in the California margin and eastern equatorial Pacific from 1.1 to 1.0 Ma

173 compared to the present day, while SSTs in the western equatorial Pacific have remained nearly

174 the same $\mathrm{e}^{44,45}$. Our study, the documentation of quantitative SSTs record near the KEF, has

175 revealed that the latitudinal temperature gradient in the north-western Pacific was small,

176 indicating the widespread WPWP from 1.1 to 1.0 Ma. Changes in SST distributions during the

177 Pleistocene are important because they are considered to be linked to the mid-Pleistocene

178 transition ${ }^{44}$. Applying the biomarker-based proxies, the Kazusa Group can provide a long,

179 continuous, and high-time resolution paleotemperature record in the Kuroshio region, which is

180 integral to understanding Pleistocene climate changes. 


\section{Methods}

\section{Biomarkers and organic compounds analysis}

Samples for biomarker analysis were freeze-dried after the surface was ultrasonically

185 cleaned with ethanol and ground into a fine powder. Sediment samples were dried and crushed

186 into a fine powder for organic matter analysis. The lipids contained in the powdered sediment

187 (approximately $3 \mathrm{~g}$ ) of each sample were extracted by sonication with dichloromethane/methanol

188 (70:30, v/v) and then saponified with $0.5 \mathrm{~mol} \mathrm{~L} \_1 \mathrm{KOH}$ in $\mathrm{MeOH}$. The saponified sample was

189 then extracted with n-hexane to obtain the neutral components. The neutral lipids were separated

190 into four subfractions by silica gel column chromatography. The $\mathrm{N}-1$ fraction (hydrocarbons)

191 was extracted with n-hexane/dichloromethane (95:5, v/v), and the N-2 fraction (ketones, esters,

192 and aldehydes) was collected with n-hexane/dichloromethane (4:6, v/v). Then, they were

193 introduced into a gas chromatograph with a mass-selective detector (GC-MS) and with a flame

194 ionization detector (GC-FID) equipped with a VF-5ms fused silica capillary column (30 m*0.25

$195 \mathrm{~mm}$ internal diameter, Agilent). The oven temperature was programmed as follows: maintained

196 at $40{ }^{\circ} \mathrm{C}$ for $2 \mathrm{~min}$, raised to $120^{\circ} \mathrm{C}$ at $30{ }^{\circ} \mathrm{C} / \mathrm{min}$, raised to $300{ }^{\circ} \mathrm{C}$ at $6{ }^{\circ} \mathrm{C} / \mathrm{min}$, and maintained

197 at $300{ }^{\circ} \mathrm{C}$ for $20 \mathrm{~min}$. Several procedural blanks, which were analyzed parallelly to the same

198 analysis, showed no $\mathrm{C}_{37}$ alkenone contamination. Analytical precisions $(1 \sigma)$ for $\mathrm{U}_{37}^{\mathrm{K}^{\prime}}$, ACL, and

199 CPI were 0.002, 0.008, and 0.004 units, respectively. The powdered samples used for biomarker

200 analysis were also used for total organic carbon (TOC) and total nitrogen (TN) analysis using a

201 Flash 2000 CHNS elemental analyser. A powdered sample (approximately $30 \mathrm{mg}$ ) was placed in

202 a silver sample boat and decalcified with a few drops of $1 \mathrm{~N} \mathrm{HCl}$ and then dried for at least $2 \mathrm{hr}$

203 at $80{ }^{\circ} \mathrm{C}$ to remove unreacted $\mathrm{HCl}$ and water. The dried samples were wrapped in a tin sample

204 boat for combustion. Quantification errors for TOC and TN were both $3 \%(1 \sigma)$ based on 
205 replicated analyses of a 2,5-bis-(5-tertbutyl-benzoxazol-2-yl)-thiophene standard. In this study,

$206 \mathrm{C} / \mathrm{N}$ ratios were used to clarify the source of organic matter, as the $\mathrm{C} / \mathrm{N}$ ratio of typical marine

207 phytoplankton organic matter is $6-7$, whereas that of terrestrial organic matter is $>12$ due to the 208 contribution of lignin-phenols ${ }^{46}$.

\section{$210 \mathrm{Mg} / \mathrm{Ca}$ ratios analysis}

$211 \mathrm{Mg} / \mathrm{Ca}$ ratios of the planktic foraminifera G. bulloides were analysed for five selected

212 siltstone beds with relatively large amounts of foraminiferal standing stock and good

213 preservation to reproduce the surface temperature. Samples for handpicking fossil foraminifera

214 were disaggregated using $\mathrm{Na}_{2} \mathrm{SO}_{4} . \mathrm{Mg} / \mathrm{Ca}$ ratios were measured using G. bulloides from the >

$215210 \mu \mathrm{m}$ size fraction. Ten or more white individuals without an oxide film were used for the

216 measurements. The samples were cleaned using the following methods outlined by ref. 47 . We

217 modified the methods for the foraminiferal tests following ref. 48. Initially, the samples were

218 gently crushed into fragments and then rinsed with methanol and ultrapure water. This process

219 was repeated until all loose material (i.e., nannofossils and clay) was removed. The samples were

220 then treated with an oxidising agent that consisted of $\mathrm{H}_{2} \mathrm{O}_{2}$ and $\mathrm{KOH}$ to remove organic matter.

221 Finally, the samples were rinsed with a mixture of $\mathrm{H}_{2} \mathrm{O}_{2}$ and $\mathrm{HClO}_{4} \mathrm{Mg}, \mathrm{Ca}$, and $\mathrm{Mn}$

222 concentrations were obtained by inductively coupled plasma mass spectrometry (ICP-MS). For

223 ICP-MS analysis, a powdered carbonate sample was transferred to Teflon vials, and $0.3 \mathrm{M} \mathrm{HNO}_{3}$

224 was added to each vial to dissolve the solids. The $\mathrm{HNO}_{3}$ used in this study was a commercially

225 supplied high-purity TAMAPURE AA-100 reagent (Tama Chemical, Japan). To control the

226 instrumental drift, internal standards (Be, Sc, $\mathrm{Y}$, and I) were added to $\mathrm{HNO}_{3}$. Additionally,

227 standard solutions prepared from JCp-1 (Geological Survey of Japan $)^{49}$ were measured for use in 
228 data correction. The relative standard deviation based on replicate measurements of JCp-1 was

$2290.5 \%(1 \sigma)$. The $\mathrm{Mn} / \mathrm{Ca}$ ratios were $0.5 \mathrm{mmol} / \mathrm{mol}$ or less for all measured samples, indicating

230 that the precleaning was sufficiently performed ${ }^{50}$. The $\mathrm{Mg} / \mathrm{Ca}$ ratios of $G$. bulloides were

231 converted to a temperature scale using the calibration in ref. 51.

232

\section{Acknowledgements}

234 We would appreciate Y. Ota, Y. Isaji, S. Furota, H. Suga, N.O. Ogawa, Y. Takano, K.M.

235 Matsuzaki and Y. Nishikura for their helpful advice and assistance in the laboratory work. T.

236 Tsuji provided information about the TR-3 core. This research was partly supported by a Grant-

237 in-Aid from the Japan Society for the Promotion of Science (18J21788) given to H. Kajita.

239 Author contributions

$240 \quad$ H. Kajita and M.U designed the project and conducted the field survey. H. Kajita and

241 A.M analyzed the samples. T.Y, N.O, A.S, and H. Kawahata organized the laboratory work and

242 assisted data interpretations. H. Kajita wrote the manuscript. All authors contributed to editing

243 and revision.

244

\section{Competing interests}

246 The authors declare no competing interests. 


\section{References}

249 1. Marlowe, I. T. et al. Long chain $\left(n-C_{37}-C_{39}\right)$ alkenones in the Prymnesiophyceae. Distribution 250 of alkenones and other lipids and their taxonomic significance. Br. Phycol. J. 19, 203-216 $251 \quad$ (1984).

252 2. Prahl, F. G., Muehlhausen, L. A. \& Zahnle, D. L. Further evaluation of long-chain alkenones 253 as indicators of paleoceanographic conditions. Geochim. Cosmochim. Acta 52, 2303-2310 (1988).

3. Müller, P. J., Kirst, G., Ruhland, G., Von Storch, I. \& Rosell-Melé, A. Calibration of the alkenone paleotemperature index $U_{37}^{K^{\prime}}$ based on core-tops from the eastern South Atlantic and the global ocean $\left(60^{\circ} \mathrm{N}-60^{\circ} \mathrm{S}\right)$. Geochim. Cosmochim. Acta 62, 1757-1772 (1998).

4. Conte, M. H., Thompson, A., Lesley, D. \& Harris, R. P. Genetic and physiological influences on the alkenone/alkenoate versus growth temperature relationship in Emiliania huxleyi and Gephyrocapsa oceanica. Geochim. Cosmochim. Acta 62, 51-68 (1998).

5. Eglinton, G. \& Hamilton, R. J. The distribution of alkanes. In Chemical plant Taxonomy (Elsevier B.V., Amsterdam, 1963).

6. Rielley, G., Collier, R. J., Jones, D. M. \& Eglinton, G. The biogeochemistry of Ellesmere Lake, UK-I: source correlation of leaf wax inputs to the sedimentary lipid record. Org. Geochem. 17, 901-912 (1991).

7. Baczynski, A. A., McInerney, F. A., Freeman, K. H., Wing, S. L. \& Bighorn Basin Coring Project (BBCP) Science Team. Carbon Isotope Record of Trace n-alkanes in a Continental PETM Section Recovered by the Bighorn Basin Coring Project (BBCP). Paleoceanogr. Paleoclimatol. 34, 853-865 (2019).

8. Sawada, K., Ono, M., Nakamura, H. \& Tareq, S. M. Reconstruction of Holocene Optimum 
paleoclimatic variations using long-chain n-alkanes and alkenones in sediments from Dabusu Lake, northeastern China. Quat. Int. 550, 27-38 (2020).

273

274

275

276

277

278

279

280

281

282

283

284

285

286

287

288

289

290

291

292

293

9. Rabinowitz, H. S., Polissar, P. J. \& Savage, H. M. Reaction kinetics of alkenone and n-alkane thermal alteration at seismic timescales. Geochemistry, Geophys. Geosystems 18, 204-219 (2017).

10. Wang, C., Eley, Y., Oakes, A. \& Hren, M. Hydrogen isotope and molecular alteration of nalkanes during heating in open and closed systems. Org. Geochem. 112, 47-58 (2017).

11. Cleaveland, L. C. \& Herbert, T. D. Preservation of the alkenone paleotemperature proxy in uplifted marine sequences: A test from the Vrica outcrop, Crotone, Italy. Geology 37, 179-182 (2009).

12. Herbert, T. D., Ng, G. \& Peterson, L. C. Evolution of Mediterranean sea surface temperatures 3.5-1.5 Ma: regional and hemispheric influences. Earth planet. Sci. Lett. 409, 307-318 (2015).

13. Ito, M. \& Katsura, Y. Inferred glacio-eustatic control for high-frequency depositional sequences of the Plio-Pleistocene Kazusa Group, a forearc basin fill in Boso Peninsula, Japan. Sediment. Geol. 80, 67-75 (1992).

14. Kazaoka, O. et al. Stratigraphy of the Kazusa Group, Boso Peninsula: An expanded and highly-resolved marine sedimentary record from the Lower and Middle Pleistocene of central Japan. Quat. Int. 383, 116-135 (2015).

15. Suganuma, Y. et al. (2018). Paleoclimatic and paleoceanographic records through Marine Isotope Stage 19 at the Chiba composite section, central Japan: A key reference for the EarlyMiddle Pleistocene Subseries boundary. Quat. Sci. Rev. 191, 406-430.

16. Gradstein, F. M., Ogg, J. G., Schmitz, M. B. \& Ogg, G. M. Geologic Time Scale 2020, Second 
Edition (Elsevier B.V., Amsterdam, 2020).

295 17. Kida, S. et al. Oceanic fronts and jets around Japan: a review. In "Hot Spots" in the Climate 296 System (Springer, Tokyo, 2016).

297 18. Tada, R., Zheng, H. \& Clift, P. D. Evolution and variability of the Asian monsoon and its 298 potential linkage with uplift of the Himalaya and Tibetan Plateau. Prog. Earth Planet. Sci. 3, 2994 (2016).

19. Hirayama, J. \& Nakajima, T. Analytical study of turbidites, Otadai Formation, Boso Peninsula, Japan. Sedimentology 24, 747-779 (1977).

20. Tsuji, T. et al. High-resolution chronology of the lower Pleistocene Otadai and Umegase Formations of the Kazusa Group, Boso Peninsula, central Japan - Chronostratigraphy of the

21. Nanayama, F., Nakazato, H., Ooi, S. \& Nakashima, R. Geology of the Mobara Distinct. Quadrangle Series, 1:50,000 (Geological Survey of Japan, AIST, Tsukuba, 2016).

22. Utsunomiya, M. \& Ooi, S. Geology of the Kazusa-Ohara Distinct. Quadrangle Series, 1:50,000 (Geological Survey of Japan, AIST, Tsukuba, 2019).

23. Kamiya, N. et al. Major variations in vitrinite reflectance and consolidation characteristics within a post-middle Miocene forearc basin, central Japan: A geodynamical implication for basin evolution. Tectonophysics 710, 69-80 (2017).

24. Prahl, F. G., De Lange, G. J., Lyle, M. \& Sparrow, M. A. Post-depositional stability of longchain alkenones under contrasting redox conditions. Nature 341, 434-437 (1989). 
Chem. 59, 219-234 (1998).

318 26. Ohkouchi, N., Kawamura, K., Kawahata, H. \& Taira, A. Latitudinal distributions of terrestrial 319 biomarkers in the sediments from the Central Pacific. Geochim. Cosmochim. Acta 61, 1911$3201918(1997)$.

321 27. Bendle, J., Kawamura, K., Yamazaki, K. \& Niwai, T. Latitudinal distribution of terrestrial lipid 322 biomarkers and n-alkane compound-specific stable carbon isotope ratios in the atmosphere 323 over the western Pacific and Southern Ocean. Geochim. Cosmochim. Acta 71, 5934-5955 (2007).

28. Rao, Z. et al. Compound specific $\delta \mathrm{D}$ values of long chain n-alkanes derived from terrestrial higher plants are indicative of the $\delta \mathrm{D}$ of meteoric waters: Evidence from surface soils in eastern China. Org. Geochem. 40, 922-930 (2009).

29. Luo, P., Peng, P., Lü, H., Zheng, Z. \& Wang, X. Latitudinal variations of CPI values of longchain n-alkanes in surface soils: Evidence for CPI as a proxy of aridity. Sci. China Earth Sci. 55, 1134-1146 (2012).

30. Zhang, J., Yu, H., Jia, G., Chen, F. \& Liu, Z. Terrestrial n-alkane signatures in the middle Okinawa Trough during the post-glacial transgression: control by sea level and paleovegetation confounded by offshore transport. Geo-Mar. Lett. 30, 143-150 (2010).

334 31. Müller, P. J., Čepek, M., Ruhland, G. \& Schneider, R. R. Alkenone and coccolithophorid species changes in late Quaternary sediments from the Walvis Ridge: Implications for the alkenone paleotemperature method. Palaeogeogr. Palaeoclimatol. Palaeoecol. 135, 71-96 (1997).

32. McClymont, E. L., Rosell-Melé, A., Giraudeau, J., Pierre, C. \& Lloyd, J. M. Alkenone and coccolith records of the mid-Pleistocene in the south-east Atlantic: Implications for the $\mathrm{U}_{37}^{\mathrm{K}^{\prime}}$ 
index and South African climate. Quat. Sci. Rev. 24, 1559-1572 (2005).

341 33. Lisiecki, L. E. \& Raymo, M. E. A Pliocene-Pleistocene stack of 57 globally distributed benthic $\delta^{18} \mathrm{O}$ records. Paleoceanography 20, PA1003 (2005).

343 34. Elderfield, H., Ferretti, P., Greaves, M., Crowhurst, S., McCave, I. N., Hodell, D., \& 344 Piotrowski, A. M. Evolution of ocean temperature and ice volume through the mid-Pleistocene $345 \quad$ climate transition. Science 337, 704-709 (2012).

35. Yamamoto, M., Oba, T., Shimamune, J. \& Ueshima, T. Orbital-scale anti-phase variation of sea surface temperature in mid-latitude North Pacific margins during the last 145,000 years.

36. Nürnberg, D., Bijma, J. \& Hemleben, C. Assessing the reliability of magnesium in 350 foraminiferal calcite as a proxy for water mass temperatures. Geochim. Cosmochim. Acta 60, 803-814 (1996).

37. Kuroyanagi, A. \& Kawahata, H. Vertical distribution of living planktonic foraminifera in the seas around Japan. Mar. Micropaleontol. 53, 173-196 (2004).

354 38. Oba, T. \& Murayama, M. Sea-surface temperature and salinity changes in the northwest 355 Pacific since the Last Glacial Maximum. J. Quat. Sci. 19, 335-346 (2004).

356 39. Oda, M. \& Yamasaki, M. Sediment trap results from the Japan Trench in the Kuroshio domain: 357 seasonal variations in the planktic foraminiferal flux. J. Foraminiferal Res. 35, 315-326 (2005). 358 40. Nürnberg, D., Müller, A. \& Schneider, R. R. Paleo-sea surface temperature calculations in the 359 equatorial east Atlantic from $\mathrm{Mg} / \mathrm{Ca}$ ratios in planktic foraminifera: A comparison to sea 360 surface temperature estimates from $\mathrm{U}_{37}^{\mathrm{K}^{\prime}}$, oxygen isotopes, and foraminiferal transfer function. $361 \quad$ Paleoceanography 15, 124-134 (2000).

362 41. Bard, E. Comparison of alkenone estimates with other paleotemperature proxies. 
Geochemistry, Geophys. Geosystems 2, 2000GC000050 (2001).

364 42. Kuroyanagi, A., Kawahata, H., Nishi, H. \& Honda, M. C. Seasonal to interannual changes in 365 planktonic foraminiferal assemblages in the northwestern North Pacific: Sediment trap results

43. Sawada, K. \& Handa, N. Variability of the path of the Kuroshio ocean current over the past 25,000 years. Nature 392, 592-595 (1998).

44. McClymont, E. L., Sosdian, S. M., Rosell-Melé, A. \& Rosenthal, Y. Pleistocene sea-surface temperature evolution: Early cooling, delayed glacial intensification, and implications for the mid-Pleistocene climate transition. Earth Sci. Rev. 123, 173-193 (2013).

45. Fedorov, A. V., Burls, N. J., Lawrence, K. T. \& Peterson, L. C. Tightly linked zonal and meridional sea surface temperature gradients over the past five million years. Nat. Geosci. 8 , 975-980 (2015).

46. Lamb, A. L., Vane, C. H., Wilson, G. P., Rees, J. G. \& Moss-Hayes, V. L. Assessing $\delta^{13}$ C and $\mathrm{C} / \mathrm{N}$ ratios from organic material in archived cores as Holocene sea level and palaeoenvironmental indicators in the Humber Estuary, UK. Mar. Geol. 244, 109-128 (2007).

47. Cheng, H., Adkins, J., Edwards, R. L. \& Boyle, E. A. U-Th dating of deep-sea corals. Geochim. Cosmochim. Acta 64, 2401-2416 (2000).

48. Yoshimura, T. et al. Altervalent substitution of sodium for calcium in biogenic calcite and aragonite. Geochim. Cosmochim. Acta 202, 21-38 (2017).

49. Okai, T. Collaborative analysis of GSJ/AIST geochemical reference materials JCp-1 (Coral) and JCt-1 (Giant Clam). Geochemistry (Chikyukagaku) 38, 281-286 (2004).

50. Hasenfratz, A. P. et al. Determination of the $\mathrm{Mg} / \mathrm{Mn}$ ratio in foraminiferal coatings: An 

approach to correct $\mathrm{Mg} / \mathrm{Ca}$ temperatures for Mn-rich contaminant phases. Earth planet. Sci. Lett. 457, 335-347 (2017).

388 51. Mashiotta, T. A., Lea, D. W. \& Spero, H. J. Glacial-interglacial changes in Subantarctic sea 389 surface temperature and $\delta^{18} \mathrm{O}$-water using foraminiferal Mg. Earth Planet. Sci. Lett. 170, 417 390 432 (1999). 


\section{Figure legends}

393 Figure 1. Maps showing overall setting of the Kazusa Group in central Japan. (a) Bold yellow 394 arrow and green dotted line represent the general path of the KC and KEF in the present day, 395 respectively. The bathymetry, plate boundaries, and locations of cores MD01-2421 and St. 14

396 (red squares) are also shown. (b) Surface distribution of the Otadai formation (yellow-coloured)

397 in the Kazusa Group (grey-coloured) on the Boso Peninsula, showing the locations of survey 398 sites in this study (red triangles) and TR-3 core (open square).

400 Figure 2. Biomarker profiles in the Yoro River section. (a) Oxygen isotope stratigraphy of the 401 TR-3 core, which is comparable to the Yoro River section ${ }^{20}$. Triangles show age-control 402 horizons established by correlation with deep sea core ODP site 677. The base of Jaramillo 403 normal subchronozone is shown with the shaded area. The intercalated key tuff beds are shown 404 with dotted lines, one of which $(\mathrm{O} 7)$ was dated by zircon fission track $(1.0 \pm 0.2 \mathrm{Ma})$. (b) $\mathrm{U}_{37}^{\mathrm{K}^{\prime}}$ $405\left(=\left\{\mathrm{C}_{37: 2}\right\} /\left\{\mathrm{C}_{37: 2}\right\}+\left\{\mathrm{C}_{37: 3}\right\}\right),(\mathrm{c}) \operatorname{ACL}\left(=\Sigma \mathrm{x}\left[\mathrm{C}_{\mathrm{x}}\right] /\left[\mathrm{C}_{\mathrm{x}}\right]\right),(\mathrm{d}) \mathrm{CPI}\left(=2 * \Sigma\left[\mathrm{C}_{\mathrm{x}}\right] /\left(\Sigma\left[\mathrm{C}_{\mathrm{y}}\right]+\Sigma\left[\mathrm{C}_{\mathrm{z}}\right]\right)\right)$, and (e) $406 \mathrm{C} / \mathrm{N}$ ratios, where \{\} and [] represents concentrations of each carbon number of LCAs and $n$ 407 alkanes, respectively $(x=27,29,31,33,35 ; y=26,28,30,32,34 ; z=28,30,32,34,36)$. Grey 408 lines connect the strata from which samples for biomarker analysis were not collected because of 409 the far distance from the key tuff beds. The error bars indicate the standard deviations based on 410 six samples taken from the siltstone bed (S-29-1-6) (Supplementary Table 1). Detailed

411 information on the sampling locations is shown in Supplementary Figure 4 and Supplementary 412 Table 2. 


\section{Tables}

415 Table 1. Comparison of multiple proxy records in strata at the same level in the Yoro River and

416 Shoryuji sections.

417

\begin{tabular}{|c|c|c|c|c|c|c|c|}
\hline & Section & $\begin{array}{c}\text { Sample } \\
\text { ID }\end{array}$ & $\mathrm{U}_{37}^{\mathrm{K}^{\prime}}$ & $\mathrm{U}_{37^{\prime}}^{\mathrm{K}^{\prime}} \mathrm{SST}\left({ }^{\circ} \mathrm{C}\right)$ & ACL & CPI & $\mathrm{C} / \mathrm{N}$ \\
\hline \multirow{2}{*}{$\begin{array}{c}\text { Directly above } \\
\text { the O7 key tuff } \\
\text { bed }\end{array}$} & Yoro River & S-26 & 0.849 & 24.4 & 30.6 & 5.69 & 6.8 \\
\hline & Shoryuji & S-18 & 0.869 & 25.0 & 30.5 & 5.44 & 6.4 \\
\hline \multirow{2}{*}{$\begin{array}{c}\text { Directly below } \\
\text { the } 07 \text { key tuff } \\
\text { bed }\end{array}$} & Yoro River & Y-05 & 0.827 & 23.7 & 30.6 & 5.66 & 10.4 \\
\hline & Shoryuji & S-19 & 0.830 & 23.8 & 30.5 & 4.92 & 8.4 \\
\hline \multirow{4}{*}{$\begin{array}{c}\text { Directly above } \\
\text { the O11 key tuff } \\
\text { bed } \\
\text { Directly below } \\
\text { the O11 key tuff } \\
\text { bed }\end{array}$} & Yoro River & $\mathrm{S}-42$ & 0.919 & 26.5 & 30.6 & 4.00 & 6.9 \\
\hline & Shoryuji & S-17 & 0.912 & 26.3 & 30.5 & 4.35 & 7.4 \\
\hline & Yoro River & Y-03 & 0.873 & 25.1 & 31.0 & 4.40 & 8.9 \\
\hline & Shoryuji & S-16 & 0.886 & 25.5 & 30.8 & 4.04 & 7.7 \\
\hline
\end{tabular}


419 Table 2. Paleotemperatures estimated from $\mathrm{U}_{37}^{\mathrm{K}}$ and $\mathrm{Mg} / \mathrm{Ca}$ ratios of Globigerina bulloides in the 420 Otadai Formation. Data from core MD01-242135,38 and St. $14^{43}$ are also shown.

421

\begin{tabular}{|c|c|c|c|c|}
\hline Location & $\begin{array}{l}\text { Sample } \\
\text { ID }\end{array}$ & MIS & $\begin{array}{c}\mathrm{U}_{37^{\mathrm{K}}-\mathrm{SST}}\left({ }^{\circ} \mathrm{C}\right) \\
\text { (Alkenone) }\end{array}$ & $\begin{array}{c}\mathrm{Mg} / \mathrm{Ca}-\mathrm{SST}\left({ }^{\circ} \mathrm{C}\right) \\
(\text { G. bulloides })\end{array}$ \\
\hline Otadai F. & S-29 & 33 & 26.1 & 23.3 \\
\hline Otadai F. & $S-32$ & 33 & 26.5 & 22.5 \\
\hline Otadai F. & S-24 & 32 & 23.6 & 21.9 \\
\hline Otadai F. & S-10 & 31 & 25.7 & 24.8 \\
\hline Otadai F. & S-26 & 30 & 24.3 & 19.9 \\
\hline MD01-2421 & & $5 e$ & ca. $20-23$ & - \\
\hline MD01-2421 & & $5 a-d$ & ca. $19-21$ & \\
\hline MD01-2421 & & 4 & ca. 18 & - \\
\hline MD01-2421 & & 3 & ca. $17-19$ & - \\
\hline MD01-2421 & & 2 & ca. $13-16$ & ca. $7-8$ \\
\hline MD01-2421 & & 1 & ca. $17-21$ & ca. $16-18$ \\
\hline St.14 & & 2 & ca. $20-22$ & - \\
\hline St.14 & & 1 & ca. $22-24$ & - \\
\hline
\end{tabular}

422

423 

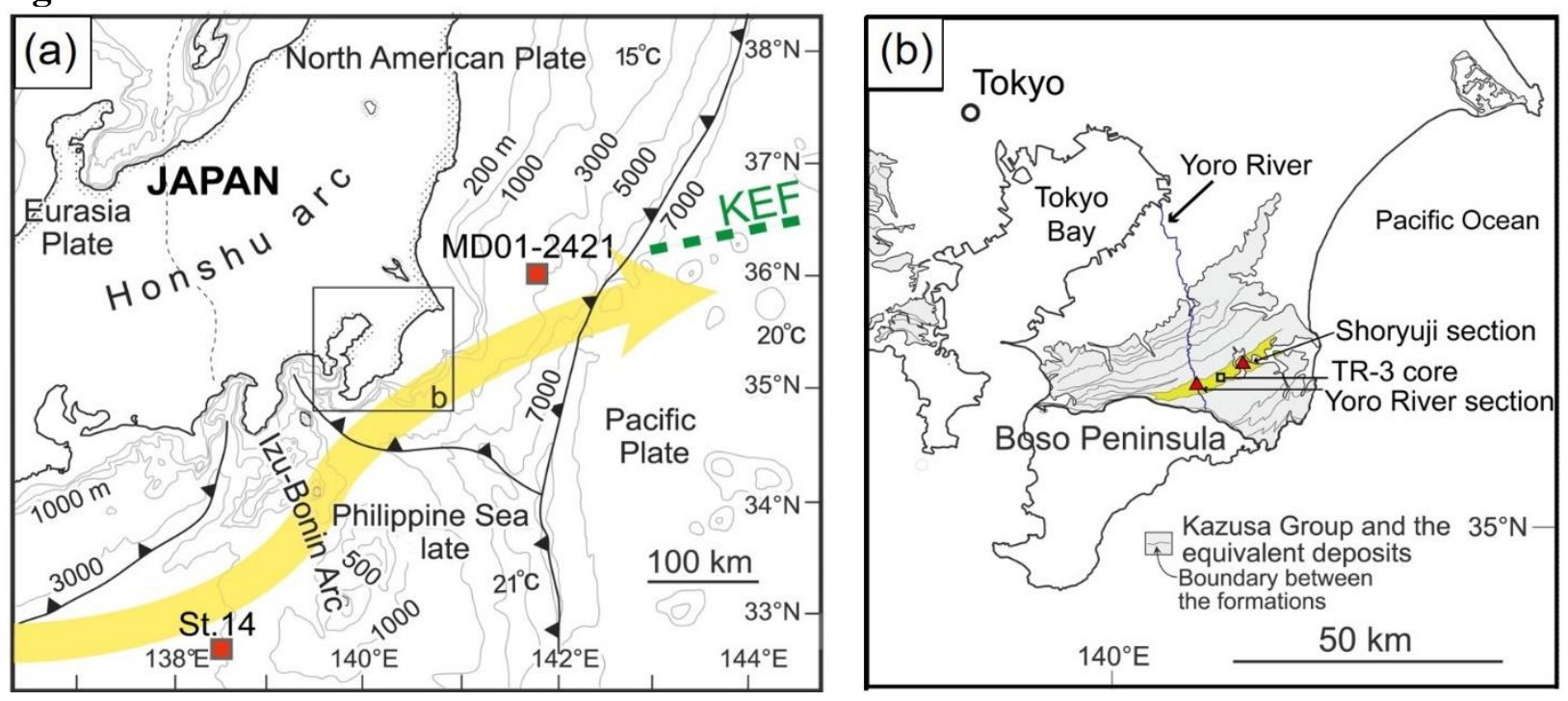

426

Figure. 1

427

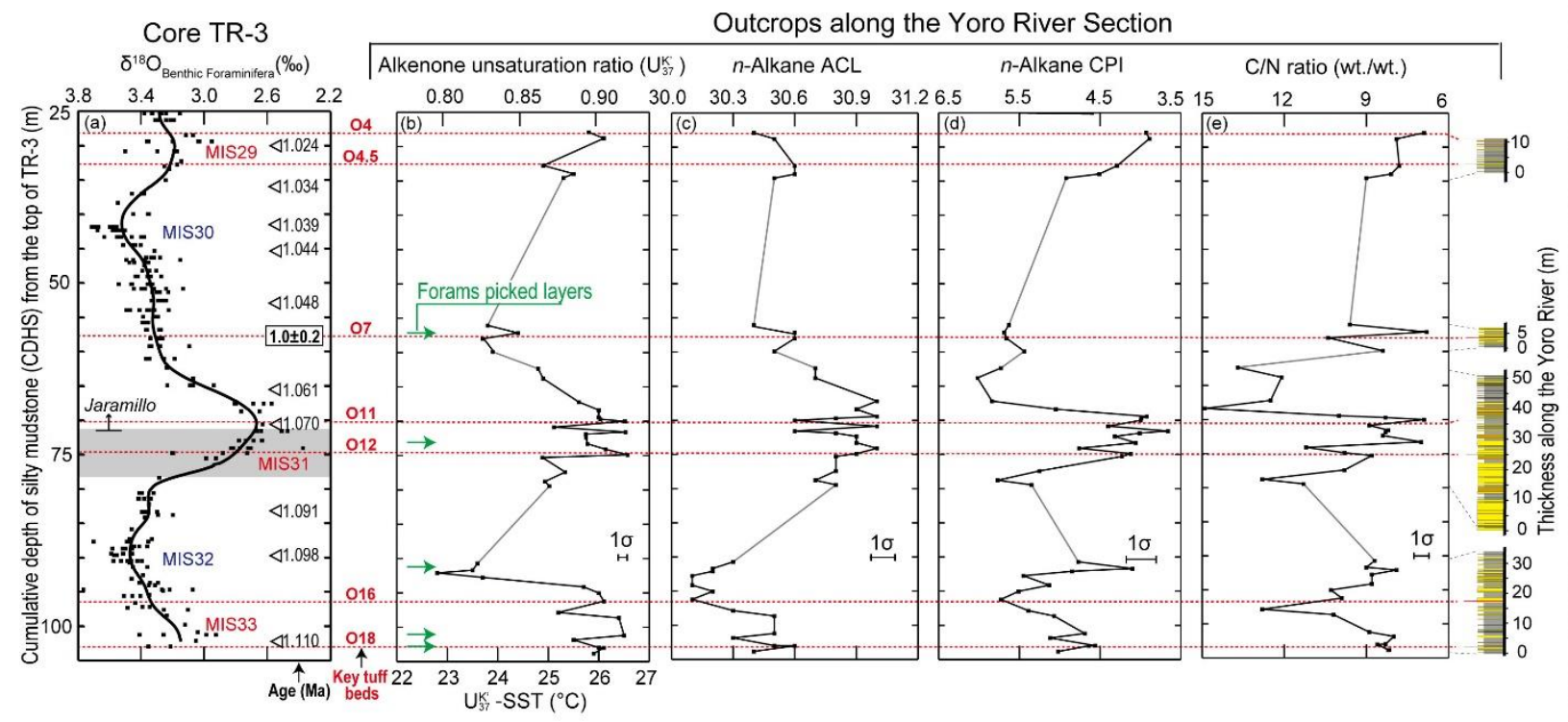

Figure. 2 

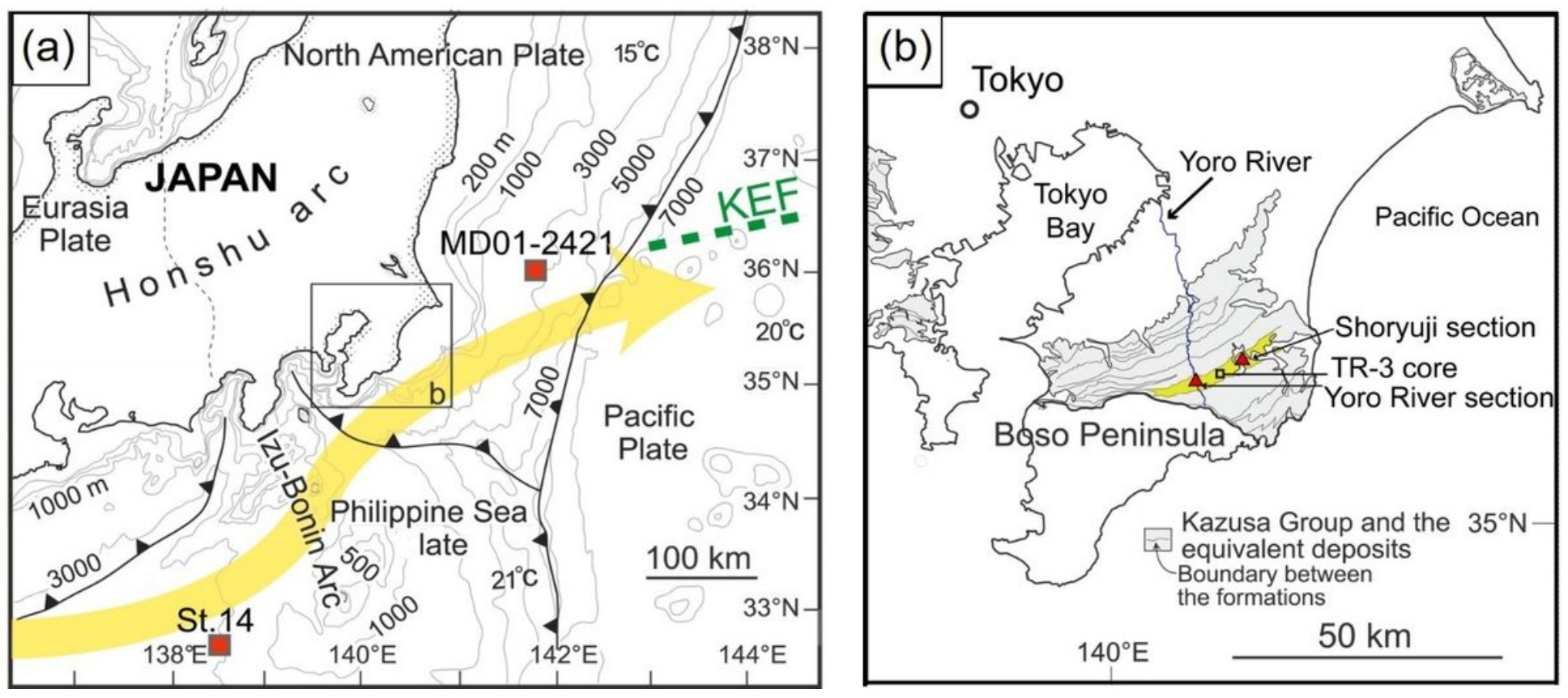

Figure 1

Maps showing overall setting of the Kazusa Group in central Japan. (a) Bold yellow arrow and green dotted line represent the general path of the KC and KEF in the present day, respectively. The bathymetry, plate boundaries, and locations of cores MD01-2421 and St. 14 (red squares) are also shown. (b) Surface distribution of the Otadai formation (yellow-coloured) in the Kazusa Group (grey-coloured) on the Boso Peninsula, showing the locations of survey sites in this study (red triangles) and TR-3 core (open square).

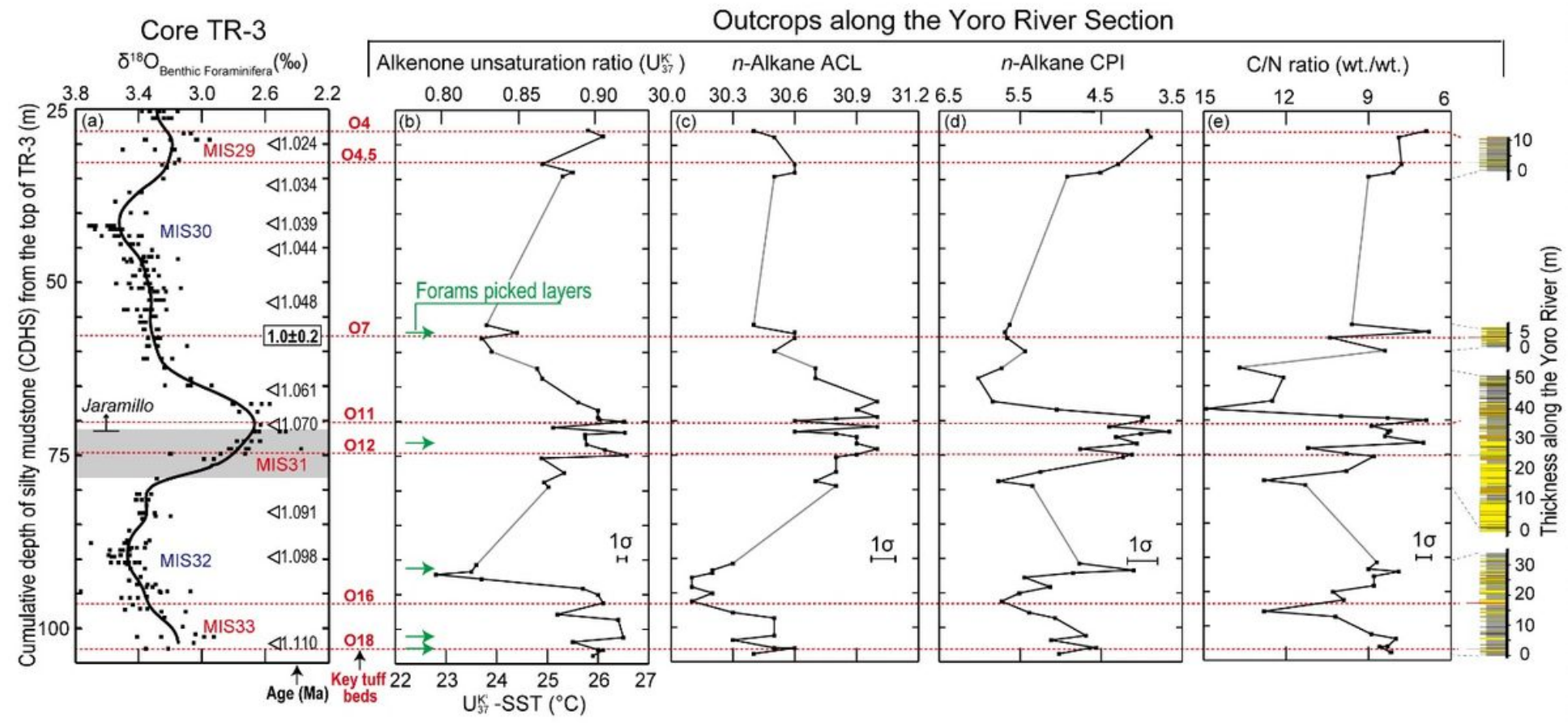

Figure 2 
Biomarker profiles in the Yoro River section. (a) Oxygen isotope stratigraphy of the TR-3 core, which is comparable to the Yoro River section20. Triangles show age-control horizons established by correlation with deep sea core ODP site 677. The base of Jaramillo normal subchronozone is shown with the shaded area. The intercalated key tuff beds are shown with dotted lines, one of which (07) was dated by zircon

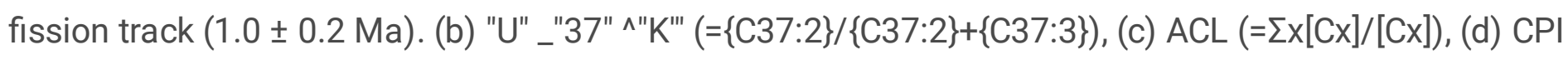
$(=2 \star \Sigma[\mathrm{Cx}] /(\Sigma[\mathrm{Cy}]+\Sigma[\mathrm{Cz}]))$, and $(\mathrm{e}) \mathrm{C} / \mathrm{N}$ ratios, where $\}$ and $[$ represents concentrations of each carbon number of LCAs and n-alkanes, respectively $(x=27,29,31,33,35 ; y=26,28,30,32,34 ; z=28,30,32,34$, $36)$. Grey lines connect the strata from which samples for biomarker analysis were not collected because of the far distance from the key tuff beds. The error bars indicate the standard deviations based on six samples taken from the siltstone bed (S-29-1-6) (Supplementary Table 1). Detailed information on the sampling locations is shown in Supplementary Figure 4 and Supplementary Table 2.

\section{Supplementary Files}

This is a list of supplementary files associated with this preprint. Click to download.

- SupplementaryMaterialscommEE.docx 